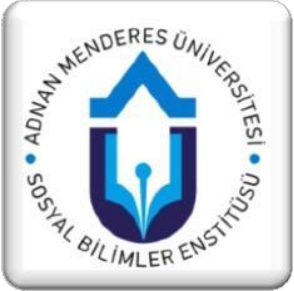

\section{Mayıs 1960 Askeri Darbesi Sonrası Milli Birlik Komitesi ve Propaganda Çalışmaları ${ }^{1}$}

\author{
Fatma TEKİN ${ }^{2}$
}

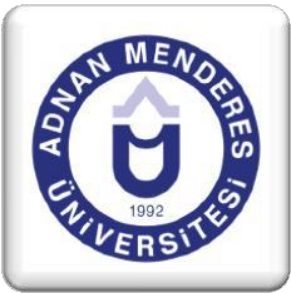

Research Article Article History

Date of Application: 19.05.2021

Acceptance Date: 08.11.2021

\title{
Özet
}

14 Mayıs 1950 genel seçimleri ile başlayan ve on yıl süren Demokrat Parti (DP) iktidarı, 27 Mayıs 1960 Askeri Darbesi ile son bulmuştur. Türkiye Cumhuriyeti tarihinde önemli bir kırılma noktası olan ilk askeri darbe sonrasında, cunta yönetimi kurulmuştur. Cunta yönetimi, yapılan darbenin haklılığını ispat edebilmek adına en güçlü silah olan propaganda araçlarına başvurmuştur. Bu doğrultuda propaganda, algı yönetimi olarak ekonomik, kültürel ve özellikle de siyasi alanda kullanılmıştır. Siyasal alanda oluşturulan algı operasyonu, DP'leri hedef almıştır. 27 Mayıs 1960 Askeri Darbesi sonrasında DP'lileri yargılamak amacıyla 12 Haziran 1960 tarihinde Yüksek Adalet Divanı'nın kurulmasına karar verilmiștir. 14 Ekim 1960'da başlayan Yassıada duruşmalarında, 395 milletvekili ve 592 sanık yargılanmıştır. Yassıada Mahkemeleri'nde tutuklu bulunanlardan Dışişleri Bakanı Fatin Rüştü Zorlu ve Maliye Bakanı Hasan Polatkan 16 Eylül 1961 tarihinde, Başbakan Adnan Menderes ise, 17 Eylül 1961 tarihinde idam edilmiştir. Bu makale ile 27 Mayıs 1960 Askeri Darbesi sonrası Milli Birlik Komitesi (MBK) idaresi ve eylemlerinin yanı sıra, DP aleyhinde yapılan siyasi propagandaların nasıl uygulanıldı ğını okuyucuya aktarmak amaçlanmıștır. Ayrıca makalede döneme kaynaklık eden gazete, dergi, broşür ve kitaplar ele alınarak değerlendirilmiştir. Çalışma sonucunda da Türk Silahlı Kuvvetleri (TSK) içindeki bir grup askerin gerçekleştirdiği 27 Mayıs 1960 Askeri Darbesi ve eylemlerini meşrulaştırma yöntemleri açıklanmıştır. Bu durum DP üyelerinin itibarsızlaştırılması ve DP'nin kapatılmasına neden olmuştur.

Anahtar Kelimeler: Propaganda, Demokrat Parti, 27 Mayıs 1960 Askeri Darbesi, Meşruiyet.

\section{National Unity Committee And Propaganda Work After May 27, 1960 Military Coup}

Abstract

Democratic Party (DP) power, starting with May 14, 1950 elections and lasting ten years, ended after May 27, 1960 military coup. After the first military coup, which was an important breaking point in the history of the Turkish Republic, the junta administration was established. In order to prove the rightness of the coup, the junta administration resorted to propaganda tools, which are the most powerful weapons. In this direction, propaganda was used as perception management in economic, cultural and especially political fields. The perception operation created in the political field targeted the party members. After May 27, 1960 military coup, it was decided to establish the Supreme Court of Justice on June 12, 1960 in order to try the DP members. At the Yassiada hearings, which began on October 14, 1960, 395 deputies and 592 defendants were tried. Among those convicted at The Yassiada courts, Foreign Minister Fatin Rüștü Zorlu and Finance Minister Hasan Polatkan were executed on September 16, 1961, and Prime Minister Adnan Menderes was executed on September 17, 1961. This article aims to convey to the reader how the administration and actions of the National Unity Committee (MBK) after the military coup of May 27, 1960, as well as political propaganda against the DP were implemented. In addition, newspapers, magazines, brochures and books referring to the period were evaluated in the article. As a result of the study, methods of legitimizing the military coup and actions of 27 May 1960 carried out by a group of soldiers within the Turkish Armed Forces (TSK) were explained. This led to the discrediting of DP members and the closure of DP.

Key Words: Propaganda, Democratic Party, 27 May, 1960 Military Coup, Legitimacy.

\footnotetext{
${ }^{1}$ Bu makale, Aydın Adnan Menderes Üniversitesi, Sosyal Bilimler Enstitüsü Tarih Anabilim Dalı'nda Prof. Dr. Dilşen İNCE ERDOĞAN danışmanlığında 2019 yılında tamamlanmış olan ve Fatma ÇELİ tarafından savunulan "1960 Askeri Darbesinde Kamuoyu Oluşturma Projesi: Propaganda” başlıklı yüksek lisans tezinden türetilmiştir.

${ }^{2}$ Doktora Öğrencisi, Dokuz Eylül Üniversitesi, Sosyal Bilimler Enstitüsü, Tarih Anabilim Dalı, ORCID ID: 0000-0002-0358-4967, fatmacelikk50@gmail.com
} 


\section{Giriş}

Darbe, askerlerin hükümeti alaşağı edip yönetimi ele geçirmesidir (Tarhan, 2017: 39). Türkiye Cumhuriyeti tarihindeki ilk askeri darbe, 27 Mayıs 1960 tarihinde gerçekleşmiştir (Tokgöz, 2010: 41). Bu eylem, Türkiye'de sivil rejimi kesintiye uğratmış ve yeni bir devrin açılmasına neden olmuştur (Mazıcı, 1989: 13). 27 Mayıs gecesi saat 03.00’ten itibaren TSK içindeki bir grup asker, Türkiye'nin her yerinde idareyi ele almıştır (Dünya, 27.05.1960: 1). DP iktidarına el konulmuş, valiler yerlerini bölgelerindeki en büyük askeri komutana bırakmışlardır (Altuğ, 1991: 22). Ayrıca Türkiye Büyük Millet Meclis’i (TBMM) dağıttılmış ve siyasi partiler faaliyetten men edilmiştir. (Daver, 1964: 45). Böylece Türkiye'de fiilen askeri yönetim başlamıştır. (Altuğ, 1991: 22)

27 Mayıs 1960 sabahı saat 05.25'de Kurmay Albay Alparslan Türkeş, Ankara Radyosundan Türk milletine ve bütün dünyaya darbenin gerçekleşme sebebini şu şekilde ilan etmiştir (Taylak, 1977: 24) :

"Aziz Vatandaşlar;

Bugün demokrasimizin içine düştügü buhran ve son müessif hadiseler dolaylslyla ve kardeş kavgasina meydan vermemek maksadiyla Türk Silahlı Kuvvetleri memleketin idaresini ele almıştır. Bu harekâta, Silahlı Kuvvetlerimiz, partileri içine düştükleri uzlaşmaz durumdan kurtarmak ve partiler üstü tarafsı bir idarenin nezaret ve hakemliği altında, en kısa zamanda adil ve serbest seçimler yaptırarak, idareyi hangi tarafa mensup olursa olsun seçimi kazananlara devir ve teslim etmek üzere girişmiş bulunmaktadır. Girişilmiş olan bu teşebbüs hiçbir şahsa veya zümreye karşı değildir. İdarelmiz hiç kimse hakkında şahsiyata müteallik tecavüzkâr bir fiile teşebbüs etmeyeceği gibi edilmesine de asla müsamaha etmeyecektir. Kim olursa olsun ve hangi partiye mensup bulunursa bulunsun, her vatandaş kanunlar ve hukuk prensipleri esasına göre muamele görecektir. Bütün vatandaşların partilerin üstünde aynı milletten, aynı soydan gelmiş evlatları olduklarını hatırlayarak ve kin gütmeden birbirlerine karşı hürmetle ve anlayışla muamele etmeleri ıstıraplarımızın dinmesi ve milli varlı̆̆ımızın selameti için zarurî görülmektedir. Kabineye mensup şahsiyetlerin Türk Silahlı Kuvvetleri'ne sı̆̆ınmalarını rica ediyoruz. Şahsî emniyetleri kanun teminatı altındadır Müttefiklerimize, komşularımıza ve bütün dünyaya hitap ediyoruz. Gayemiz Birleşmiş Milletler Anayasası'na ve İnsan Hakları Prensiplerine tamamiyla riayettir. Atatürk'ün 'Yurtta sulh, cihanda sulh' prensibi bayrağımızdır. Bütün ittifaklarımıza ve taahhütlerimize sadı̆̆ız. NATO'ya (North Atlantic Treaty Organization-Kuzey Atlantik Antlaşması Örgütü) inanıyoruz ve bağllyız, CENTO'ya (Central Treaty OrganizationMerkezi Antlaşma Teşkilatı) inanıyoruz ve bağllyız. Tekrar ediyoruz düşüncemiz 'Yurtta sulh, cihanda sulh 'tur' (Ahmad, 2006: 157-158).

27 Mayıs 1960 Askeri Darbesi niçin yapılmıştı ve DP iktidarının devrilmesini gerekli kılan sebepler neydi? Bu sorunsala çözüm olarak, "memlekette demokrasiyi bütün müesseseleriyle yeniden kurmak, keyfi ve partizan idarenin yerine kanunlar karşısında vatandaşlara eşit muamele tatbik eden bir hukuk devleti nizami tesis etmek, suistimalleri tamamen ortadan kaldırıp milletin tek bir kuruşunun bile israfina müsaade ve müsamaha etmemek, her vatandaşl, kabiliyeti ve say-ü gayreti nispetinde para kazanarak refaha erişmeyi mümkün kılan bir çalışma ve kazanma serbestine sahip kilmak, Türk parasının dâhilde ve hariçte kıymetini yükselterek vatandaşın satın alma gücünü artıran bir mali politikanın tedbirlerini bulmak, her hizmette planl hareket etmeyi son olarak kabul etmek" şeklinde özetlenmiştir (Başkanlık Cumhuriyet Arşivi (BCA), 30-1-0-0/1-10-2, 08. 07. 1960).

27 Mayıs 1960 Askeri Darbesi, Türk basınında "Centilmen Ihtilal, Ak Devrim, Gülen Ihtilal, Beyaz Ihtilal ve Seçkin Devrim" olarak nitelendirilirken; Dünya basınında, "En asil ve kibar 
bir ihtilal" olarak adlandırılmış ve geniş bir yankı uyandırmıştır (Çelik, 2019: 84-85). 27 Mayıs 1960 Askeri Darbesinin manasına ilișkin olarak 30 Mayıs 1960 tarihli Akis Dergisi'nde Metin Toker, “Meşruiyet yoluyla kurulmasına rağmen gayrı meşru bir fiilî idare haline düşmüş Menderes rejimine karşı meşru bir fiili idarenin kurulması hareketi" olarak ifade etmiştir. Bu doğrultuda düşürülen DP iktidarı için, "meşruiyetini kaybettiği" vurgusu yapılmıştır (Akis, 30.05.1960: 4). Aynı zamanda başarı ile sonuçlanan darbenin meşru olduğu düşüncesi kamuoyunda geçerli k1lınmak istenmiştir. (Demirel, 2011: 246). Bu sebeple darbe yoğun bir propaganda, dedikodu ve yalanlar ile beslenerek DP'ye karşı kullanılmıştır. Özellikle de 27 Mayıs öncesi başlayan girişimler, sonrasında filizlenerek darbeyi beraberinde getirmiştir. Propaganda girişimlerin temelinde ise; bir darbeye aracı olacak şekilde sebep oluşturmak, kamuoyu yaratmak ve yapılacak olan darbenin yine kamuoyunun belirli bir kesimi tarafindan destek aktarımını sağlayabilme düşüncesi yatmaktadır (Koçak, 2017: 13).

27 Mayıs 1960 Askeri Darbesini gerçekleştirenler arasında bulunan Kurmay Binbaşı Orhan Erkanl1; "Anilar, Sorunlar, Sorumlular" adlı eserinde 27 May1s 1960 Askeri Darbesi ile ilgili düşüncelerini şu şekilde belirtmiştir: "Ihtilallerin, askeri darbelerin, değişmez özelliği; gizli örgütler tarafindan gerçekleştirilmiş olmalarıdır... Gizlilik ve emniyet unsurları hazırlık ve olus safhalarının yazll olarak tespitine imhan vermez. Filhakika 27 Mayls öncesine ait elimizde hiçbir yazll vesika yoktur. Böylece tarih en güvenilir kaynaktan yoksun kalır. Olayları aydınlı̆̆a çıkarmak, yazmak ve yaymak isteyenlerin başvuracakları yegâne kaynak, hadiseleri yaratmıs ve yaşamış olanların yazılan veya sözleridir. Çoğu hallerde bunlar da kısır, sınırlı ve eksik bilgilerdir. Tarafsızlıkları, bütünlükleri ve hatta doğrulukları şüphelidir." (Demirer, 2012: 33) Görüldüğü üzere TSK içerisindeki bir grup askerin gizlice teşkilatlandığı, bu durumun yazılı kaynaklara erişimi ve tarafsızlığı engellediği için cunta tarafından darbe sonrası kaynaklardaki söylemlerin birlik arz ettiği belirtilmiştir. $\mathrm{Bu}$ doğrultuda MBK, kamuoyunun desteğini sağlamak adına geniş çaplı propaganda çalışmalarına girişmiştir. İktidar aracı olarak propaganda uygulamalarının yönünün belirlenmesinde ve o dönemin perspektifinden 27 Mayıs 1960 Askeri Darbesinin Türkiye Cumhuriyeti'nin ilk darbesi olup sonrasında yarattığı etkiler ve MBK tarafından yürütülen faaliyetler ele alınarak değerlendirilmiştir.

\section{Askeri Cunta: Milli Birlik Komitesi (MBK)}

Meşruluğunu yitirdiği iddia edilen bir siyasi iktidar, ahlaki ve siyasi meşruluk iddia eden bir diğer grup tarafından alaşağı edilmiş, eski siyasal düzen değiştirilmiştir (Demirel, 2011: 17). Değişen siyasal düzeni Türk Silahlı Kuvvetlere mensup 38 subay, gerçekleştirmiştir. 38 kişiden oluşan MBK üyeleri: "Org. Cemal Gürsel, Kur. Alb. Ekrem Acuner, Bnb. Fazıl Akkoyunlu, Kur. Alb. Refet Aksoyoğlu, Hv. Kur. Alb. Mucip Atakll, Tümg. İran Baştuğ, Yzb. Rifat Baykal, Hv. Kur. Yarbay Emanullah Çelebi, Yzb. Ahmet Er, Kur. Bnb. Orhan Erkanl,, Kur. Bnb. Vehbi Ersü, Kur. Yzb. Numan Esin, Kur. Bnb. Suphi Gürsoytrak, Kur. Yarbay Orhan Kabibay, Kur. Bnb. Kadri Kaplan, Kur. Yarbay Mustafa Kaplan, Kur. Yarbay Suphi Karaman, Bnb. Muzaffer Karan, Kur. Yzb: Kamil Karavelioğlu, Kur. Alb. Osman Köksal, Dz. Kur. Bnb. Münir Köseoğlu, Kur. Alb. Fikret Kuytak, Kur. Alb. Sami Küçük, Tümg. Ceml Madanoğlu, Kur. Alb. Sezai Okan, Kur. Yzb. Muzaffer Özdă̆, Org. Fahri Özdilek, Kur. Bnb. Mehmet Özgüneş, Kur. Bnb. Selahattin Özgür, Kur. Bnb. Şükran Özkaya, Yzb. Irfan Solmazer, Kur. Bnb. Şefik Soyuyüce, Bnb. Dündar Taşer, Kur. Alb. Haydar Tunçkanat, Kuır. Alb. Alparslan Türkeş, Tuğg. Sitkı Ulay, Kur. Yarbay Ahmet Yıldız, Kur. Alb. Muzaffer Yurdakuler" olarak sıralanmıştır. Fakat 27 Mayıs 1960 Askeri Darbesinden sonra Tümgeneral İrfan Baştuğ'un (Demirer, 2012: 19-20) trafik kazasında hayatını kaybetmesiyle MBK'nin üye sayısı 37'ye düşmüştür (Karavelioğlu, 2007: 57). 
Genç subayların gerçekleștirdiği 27 Mayıs 1960 Askeri Darbesi; çelişkili, anlaşılması zor, plan ve programdan yoksun, stratejisiz bir biçimde gerçekleşmiştir. Ayrıca emir - komuta zinciri içinde yapılmamış tek darbedir. Bu özellikleri ile 27 Mayıs; 12 Mart Muhtırası, 12 Eylül 1980 ve 28 Şubat ile karşılaştırıldığında diğer süreçlerden farklıdır (Ersoy ve Çetinbaş, 2010: 25).

Konuya ilişkin olarak MBK üyelerinin hatıralarında yer alan düşünceler bunun göstergesidir. Kurmay Binbaşı Orhan Erkanl1; "Elbette her ihtilalin bir yönü, gayesi olmalıdır. Sadece yıkmak veya yıkılan yere oturmak için ihtilal yapılması düşünülemez. Ancak bu yönün, hedefin mutlaka klasik ölçülere uygun olarak ve săg, sol, orta vs. gibi sözlerle ifade edilmesi de gerekli değildir ve hatta zararlıdır. 27 Mayısçıların ihtilal sonrası için bir planları yoktu, fakat ekseriyetin fikrine dayanan prensipleri vardl" açıklamasını yapmıştır. Dündar Seyhan ise; "İhtilale karar vermiştik. Bu ihtilalle Türkiye'ye neler getirmek istiyorduk? Ihtilal hangi fikir bazına dayanacaktı? İhtilal mi fikirden, fikir mi ihtilalden doğacaktt?... O günlerde itiraf ederim ki elimizde, yazılı olarak, Türkiye'nin yarının hedefleyen, ihtilal sonrası bir program mevcut değildi...” demiş̧ir (Taylak, 1977: 19). Bir diğer Kurmay Albay Alparslan Türkeş ise; "Toplantılar yapıllyordu. İhtilal için çeşitti gruplar kendi aralarında çalışma halinde idiler. Bu toplantılar da Demokrat Parti iktidarı hakkında çok ağır ithamlar yapılıyordu. Illeri geri hakaret dolu sözler söyleniyor, "Bunları asmall, kesmeli, şöyle olmall, böyle olmadl" deniyor... Bana teklifte bulunulduğunda, "Ne yapacağız, Nedir hedef, gaye" dediğim zaman, "Bunlart yıkacağız. Ondan sonra da İsmet Paşa'yl getireceğiz. Cumhuriyet Halk Partisini getireceğiz" gibi fikirler öne sürülüyordu. Bana öyle ifrata kaçıllyordu ki, bu Demokratların ocak, bucak başkanlarına varıncaya kadar, hepsi ağır bir şekilde ezilmeli, cezalandırllmall, aksi halde memleketin düzelmesi mümkün değildir, gibi görüşler yer alıyordu" şeklinde dile getirmiştir (Taylak, 1977: 19-20). Buradan hareketle, darbenin bir fikri ve ideolojik platformu olmadığı bilinmektedir (Altuğ, 1991: 28). Ülkenin içinde bulunduğu sorunlara alternatif oluşturacak önceden planlanmıș bir projesi ve eylem planı olmayışı bundan dolayıdır. Yönetimi ele alan askeri cunta, bünyesinde karışık bir hizipler koalisyonunu barındırmaktadır. Cuntanın 38 üyeden oluşmasının sebebi de, temsil edilmek isteyen ve aralarında uzlaşıya varmayan birçok gizli gruptan oluşmasıdır (Ahmad, 1995: 179-181). 27 Mayıs 1960 Askeri Darbesinin ardından lider arayışında olan cunta, liderlerinin kim olacağı sorununa çözüm olarak hiziplerin dışında kalması nedeniyle Orgeneral Cemal Gürsel'i (1895-1966), uygun görmüştür. MBK'nin başına getirilen Orgeneral Cemal Gürsel; 2 Haziran 1960'dan itibaren Devlet Başkanı, Başbakan ve Milli Savunma Bakanı olarak seçilmiştir. 10 Ekim 1961'de ise, Meclis'te yapılacak olan seçimle Cumhurbaşkanlığı'na getirilecektir (Aydın ve Taşkın, 2014: 72).

27 Mayıs 1960 günü yapılan toplantı da darbe hükümetinin üç bakanlık dışında sivillerden oluşması kararı alınmıştır. 28 Mayıs'ta ise, hiç vakit kaybetmeden (Özdağ, 1997: 256) Hükümet kuruldu (Vatan, 29.05.1960: s.1). Hükümet, MBK'nin 27 numaralı tebliğ ile ilân edilmiştir:

"Milli Birlik Komitesince uhdeme tevdi edilen Başbakanlık görevi icabı hükümet aşağıdaki zevat tarafindan teşkil edilmiştir. Bu hükümetin teşkilinde dikkat nazarına alınan fikrimüdir memleket ve dünya çapında şöhret yapmış fakat herhangi bir siyasi partiye resmen mensup olmayan personelden ibaret olmasidır. Yakın mesai arkadaşlarıma yeni vazifelerinde başarılar temenni eder, Türk Milletine hayırlı olmalarını dilerim." 


\begin{tabular}{|l|l|}
\hline Başvekil ve Milli Müdafaa Vekili: & Orgeneral Cemal Gürsel \\
\hline Devlet Vekili: & Amil Artus \\
\hline Devlet Vekili: & Şefik İnan \\
\hline Adliye Vekili: & Abdullah Gözübüyük \\
\hline Dâhiliye Vekili: & Tümgeneral Muharrem İhsan Kızıloğlu \\
\hline Hariciye Vekili: & Selim Sarper \\
\hline Maliye Vekili: & Ekrem Alican \\
\hline Maarif Vekili: & Prof. Dr. Fehmi Yavuz \\
\hline Nafia Vekili: & Daniş Koper \\
\hline Ticaret Vekili: & Cihat İren \\
\hline Sıhhat ve İçtimai Muavenet Vekili: & Prof. Dr. Nusret Karasu \\
\hline Gümrük ve İnhisarlar Vekili: & Fethi Aşkın \\
\hline Ziraat Vekili: & Feridun Üstün \\
\hline Münakalat Vekili: & Tuğgeneral Sıtkı Ulay \\
\hline Çalışma Vekili: & Prof. Dr. Cahit Talas \\
\hline Sanayi Vekili: & Muhtar Uluer \\
\hline Basın-Yayın ve Turizm Vekili: & Zühtü Tarhan \\
\hline İmar ve İskân Vekili: & Orhan Kubat \\
\hline
\end{tabular}

(T.C. Resmi Gazete, 30.05.1960, Sayı: 10515: 1)

30 Mayıs 1960 Pazartesi günü saat 10.00'da ise yeni kabine, MBK Başkanı ve Başvekil Cemal Gürsel'in başkanlığında ilk toplantısını yapmıştır. Bu toplantıda yeni kabinenin alacağı tedbirler şu şekilde bildirilmiştir: Vatandaşların demokratik nizamlar çerçevesinde maddi ve manevi huzura kavuşturulması için gerekli tedbirlerin alınacağı, herkesin eşit hak ve hürriyete sahip olacağı, parti faaliyetlerinin geçici olarak durdurulacağ 1 , esas hak ve hürriyetleri tehdit eden kanun ve hükümlerin kaldırılması ve konuya ilişkin Adalet Bakanlığı'nın kısa zamanda gerekli hazırlıkları yapmasına; iktisadi durumun yeniden düzenlenmesi için gerekli tedbirlerin alınmasına; gerek dost memleketler gerekse bütün dünya milliyetleriyle dostça ilişkilerde bulunmasına ve barışa hizmetin dış politikanın temel prensibi olarak kabul edilmesine karar verilmiştir. (Başkanlık Cumhuriyet Arşivi (BCA), 30$18-1-2 / 155-1-1,30.05 .1960)$

Hükümeti kurduktan sonra MBK, 1924 Anayasası'nın birçok hükmünde büyük ölçüde değişikliğe gitmiştir. İlginç olanı devrik DP iktidarının anayasayı ihlal etmesi gerekçe gösterilmişse de MBK, ihlal edilen anayasayı savunmamış onun yerine geçici bir anayasa ilan etmiştir (Koçak, 2017: 50). 1 Numaralı Geçici Anayasa, MBK'nin görev ve yetkisini belirleyerek resmileştirmiştir. 12 Haziran'da kesinleşen Geçici Anayasa, 14 Haziran'da yürürlüğe girmiştir (Karavelioğlu, 2007: 56). MBK üyeleri kendi aralarında, "Bir karşılık beklemeden, ahlâk, adalet, hukuk ve insan haklarl prensiplerinden ve vicdani kanaatlerimden başka bir sinırla bağlı olmaksızın kendimi Türk Milletine adadım. Vatanın ve Milletin mutluluğuna ve Milletin egemenliğine aykır bir ülkü gütmeyeceğim. Demokratik Cumhuriyeti yeni Anayasaya göre düzenlemek ve iktidarl yeni Meclise devretmek ülküsüne bağlllıktan ayrllmayacağım. Bunun için şerefim, namusum ve bütün mukaddesatım üzerine 
and içerim" metni ile yemin ederek görevlerine başlamışlardır (T.C. Resmî Gazete, 14.06.1960, Say1: 10525: 1).

Zayıf bir hükümetle yola çıkan MBK, kendi içindeki hazırlıksızlıklara ve uyumsuzluklara rağmen hayatın düzene girmesi için küçük de olsa bazı adımlar atmış, kilit noktalara tayinler gerçekleștirmiştir (Özdağ, 1997: 257). 13 Temmuz 1960 tarihli Kim Dergisi'nde de konuya ilişkin; 27 Mayıs 1960 Askeri Darbe sonrasında özellikle İçişleri Bakanlığı'nda büyük ölçüde islahat yapıldığına; birçok vali ve kaymakam kadrolarında nakil ve tayinlerin gerçekleştiğine değinilmiştir. Bazı DP idarecilerinin görevden ayrıldığı konusuna da yer verilmiştir. Darbeden sonra da İçişleri Bakanlığı'nda istifaların durduğuna vurgu yapılmıştır. Bu dönemi, "Polissiz Devir" olarak nitelendirerek İstanbul ve Ankara şehirlerinde, hukuk tarihinde yer alacak bir devir yaşandığını, devrin 28 Nisan'da başladığını ve inkılap hareketinin yapılmasından bir hafta sonraya kadar devam ettiği dile getirilmiştir. Üstelik MBK idaresi ile memleketin her tarafında asayişin sağlandığı ve kargaşa ortamının sona erdiği belirtmiştir (Kim, 13.07.1960, Y11:3, Say1:105: 10-11).

Ancak MBK içinde birtakım anlaşmazlıklar baş göstermiştir. 27 Mayıs 1960 Askeri Darbesini hazırlayan subayların MBK adı altında seçimler yapılıncaya kadar iktidarda kalmaları, prensip yönünden kabul edilmiştir. Fakat alınan bu karara Orgeneral Cemal Gürsel, 27 Mayıs 1960 Askeri Darbesinin başarılı olması gerekçesiyle karşı çıkmıştır. Orgeneral Cemal Gürsel, subayların ordudaki görevlerine geri dönmeleri gerektiğini ileri sürerken; bu karara sıcak bakmayan subaylar ise çoğunluktaydı. Onun yerine bir kısım subay, iktidarda kalarak hiçbir siyasi partinin başaramayacağına inandıkları reformları gerçekleştirmeyi hedeflemiştir. Ayrıca iktidarı Orgeneral Cemal Gürsel'e bırakılması durumunda Orgeneral Cemal Gürsel'in bir dikta yönetimine gitmesi ihtimalinden çekinen subaylar da bulunmaktaydı. İstanbul'dan çağırılan profesörlerin tavsiyesi üzerine, MBK'nin iktidarda kalmasının ve seçimler yapılıncaya kadar yürütme yetkisini elinde bulundurması gerektiği kararına varılarak söz konusu belirsizlik çözülmüştür. Bunun üzerine Başbakanlık'ta MBK adı altında toplanan subaylar, sürekli toplantılar yapmıştır. Fakat MBK'nin çalışmalarında bir düzensizlik ve karışıklık söz konusu idi. Üstelik 27 Mayıs 1960 Askeri Darbesi öncesi bir komitenin kurulacağı düşünülemediği için MBK'ne kimlerin dâhil olup olmadığı da belli değildi. Ayrıca 27 Mayıs 1960 Askeri Darbesini gerçekleştiren subaylar arasında hangi meselelerin ne şekilde görüşüleceği hususunda da bir düzen kurulamamıştır (Milliyet, 15.03.1965: 5).

MBK ve aralarındaki görüş ayrılıklarını Bülent Ecevit ise, "Millî Birlik Komitesi üyeleri zaman zaman kendi adlarına konuşmalar yapıyorlar. Daha doğrusu, konuşmalarından bazısının kendi adlarına olduğu Millî Birlik Komitesini bağlamadı̆̆ sonradan anlaşıllyor. Devlet ve Hükümet Başkanı Sayın Cemal Gürsel, her basın konferansinda, Millî Birlik Komitesi'nin de başı olarak, Komite üyelerinden bazllarının konuşmalarını tavzih etmek, bunların Komiteyi bă̆lamadı̆̆ını, Komite görüşlerini yansıtmadı̆̆ını belirtmek ihtiyacını duyuyor. Son basin konferansında, Sayın Gürsel, kendi konuşmalarından biri için bile böyle bir tavzih de bulunmuştur... Gerçi, M.B.K. bir parti programına dayanmadı̆̆ için, bu kurulun belirli konularda görüş birliğine varması kolay olmayabilir..." ş̧eklinde ifade etmiştir (Ecevit, 1960: http://ecevityazilari.org/items/show/1262, Erişim Tarihi: 06.02.2021). $\mathrm{Bu}$ sorun MBK içinde ayrılıkları da beraberinde getirmiştir. 14 Komite üyesi, memleket menfaatlerini tehlikeye düşürdüğü gerekçesi ile Komiteden çıkarılmıştır. 14'ler olarak nitelendirilecek olan bu Komite üyelerinin ihracı üzerine 13 Kasım 1960 tarihinde birinci komite feshedilerek yerine yirmi üç üyeli ikinci bir Komite kurulmuştur (Hürriyet, 14.11.1960: 1). Konuya ilişkin olarak Devlet Başkanı Orgeneral Cemal Gürsel, "Komitedeki fikir ayrllıklarının millete endişe ve itimatsızlık yarattığını" dile getirmiştir. Kurucu 
Meclis'in çalışmaya başlayacağını, bundan sonra hiçbir müessesede tasfiye olmayacağını belirtmiştir (Milliyet, 14.11.1960: 1). Fakat üniversitelerde de tasfiye uygulandığ görülmüştür. MBK, yayınladığı bir kanunla İstanbul, Ankara, Ege, Atatürk ve Teknik Üniversitelere mensup 147 öğretim üyesinin işlerine son vermiştir (Hürriyet, 28.10.1960: 1).

6 Ocak 1961 tarihinde açılan Kurucu Meclis için, "2. Cumhuriyetin temelinin atıldĭ̆gl” ve "Devrimden 225 gün sonra Meclis 'in açıldĭ̆ı" belirtilmiştir (Akşam, 07.01.1961: 1). Kurucu Meclis tarafından 9 Temmuz 1961'de Anayasa hazırlanmıştır. Anayasa halkoylamasına sunulmuş ve \% 60, 4 “evet” oranıyla kabul edilmiştir (Akşin, 2009: 242). Türkiye'de ilk kez yapılan halkoylaması sonrası, 1961 Anayasası kesin olarak yürürlüğe girmiştir (Turan, 2002: 57-58). 27 Mayıs 1960 Askeri Darbe sonrası yeni Anayasa ve Seçim Yasası'nın öngördüğü ilk seçimler, 15 Ekim 1961'de yapılmıştır (Turan, 2002: 82). Genel seçimlerden sonra Meclis, 25 Ekim 1961'de toplanarak MBK askerî rejimine son vermiştir (Turan, 2002: 86).

\section{Milli Birlik Komitesi’nin (MBK) Yürüttüğü Propaganda Faaliyetleri}

MBK'nin 27 Mayıs günü gerçekleştirdiği darbe ile başlayan tek başına yönetimi, 25 Ekim 1961'de son bulmuştur (Turan, 2002: 86). Bu dönem aralığı, "MBK faaliyetleri" olarak nitelendirilmiştir. Söz konusu bu faaliyetler arasında belli başlı olanları ise şu şekilde sıralanmaktadır: DP üyelerinin Yüksek Adalet Divanı'nda yargılanması, (Burçak, 1976: 194) DP'nin kapatılmas1, (Yeni Asır, 30 Eylül 1960: 1) hemen ardından tüm partilerin ocak-bucak örgütlerinin kapatılması, (Mazıcı, 1989: 119) 14'ler olarak adlandırılan MBK içerisinden 14 üyenin ihraç edilmesi, (Koçak, 2017: 51) 147'ler olayı olarak bilinen 147 öğretim üyesinin üniversitelerden ihraç edilmesi (Koçak, 2017: 113) ve son olarak orduda beş bin kadar subayın emekliye sevk edilmesidir (Koçak, 2017: 115).

MBK'nin bir diğer hareketi de üniversiteden köye gerçekleştirdiği propaganda faaliyetleridir. Propaganda faaliyetlerini yürütmek, 27 Mayıs 1960 Askeri Darbesinden sonra darbenin önemini, amacını tüm Anadolu halkına anlatmak ve meşruluğunu sağlamak için İçişleri Bakanlığı tarafından "İnkılap Büroları" oluşturulmuştur. Bu bürolarda olmak üzere MBK tarafindan iki bin bilim ve sanat insanı görevlendirilmiştir. İstanbul, İstanbul Teknik, Ankara, Ege ve Atatürk Üniversitelerinden beş yüz kadar profesör, doçent ve asistan Ankara'da bir araya gelerek 20 Eylül - 5 Ekim 1960 tarihleri arasında Orta Anadolu, Doğu Anadolu ve Güneydoğu Anadolu illerini dolaşmışlardır. 27 Mayıs İnkılabını Yayma Komiteleri ve İnkılap Büroları aracılığıyla yapılan bu faaliyetlerden bazılarında köylere gazetelerin uçakla atıldığ da bilinmektedir (Atılgan vd., 2015: 544). Ayrıca bu propaganda faaliyetleri kapsamda belli başlı yerlerde birer gazete sandığı yaptırılmış ve toplan gazetelerin her gün köylere gönderilmesi sağlanmıştır. Böylece günde ortalama iki yüz elli bin gazete toplanarak köylere sevk edilmiştir. Fakat sonradan bu sistemin sekteye uğradığı ve sandıkların çöp sandığı haline getirildiği bilinmektedir (Türkeş vd., 1964: 9). Aynı amaçlar doğrultusunda DP'nin ülkede bıraktığı hasarları halka anlatmak ve darbenin ruhunu halka yaymak için geziler düzenlenmiştir. Devlet ve Hükümet Başkanı olarak Orgeneral Cemal Gürsel'in yurt içi gezilerini tertiplediği iller arasında; Erzincan, Erzurum, Trabzon ve Sivas yer almaktadır (Ak Devrim, 1960: 289).

Bununla birlikte sanat ve kültür çalışmaları kapsamında 17 Ağustos 1960'da Türk Kültür Dernekleri açılmıştır. Devlet Başkanı Orgeneral Cemal Gürsel, Türk Kültür Derneklerinin aç11ış konuşmasında, "Milleti içinde bulunduğu şaşkın durumdan kısa zamanda kurtarıp milli hedefe yöneltebiliriz" diyerek kapatılan Halkevlerinin, bu derneklere verildiğini ifade etmiştir (Cumhuriyet, 17.08.1960: 1). Türk Kültür Dernekleri, DP'ye gönül veren kırsal çoğunluğun rızasını örgütleyerek onları milli hedefler doğrultusunda seferber etmeyi amaçlamıştır (Atılgan vd., 2015: 544). Türk Kültür Derneklerinin kurulması, tüzüğünün 
hazırlanması gibi faaliyetler, o zamanki Milli Eğitim Bakanı'nın başkanlığında ve yine Milli Eğitim Bakanlığı (MEB) kadrosundan kurulmuş bir grup tarafından yürütülmüştür (Türkeş vd., 1964: 7-8).

Bu gelişmelerin yanı sıra MBK'nin 27 Mayıs 1960 Askeri Darbesi sonrasında devraldığı hazinenin durumunun pek iç açıcı olmayışının ardından belli başlı tedbirler alınmıştır. Böylece ülkenin dört bir yanında bağış kampanyası başlatılmıştır (Turan, 2002: 55). Öncelikle ordu mensuplarının bağış kampanyasında halka örnek olması açısından destek olduğu ve alyanslarını hazineye bağışladıkları bilinmektedir. Başlatılan bağış kampanyasının gazetelere de yansıdığı ve kampanyaya genişçe değinildiği görülmüştür (Alkan, 2017: 217218). Konuya ilişkin olarak 9 Haziran 1960 tarihli Milliyet Gazetesi'nde, “Ordu mensupları ziynet eşyasını hazineye veriyor" başlı̆̆ının devamında "Hazinenin altın stokunu takviye maksadiyla I. Zırhlı Tugay ve mensuplarının teşebbüsü ile başlayan harekete halk da katıllyor" şeklinde dile getirilmiştir (Milliyet, 09.06.1960: 1). Ekonomik tıkanıklığı giderme amacına yönelik alınan tedbirlere karşılık halk ise; nişan/evlenme yüzüklerini, altın kolye, zincir ve bileziklerini devlete bağışlamak için seferber oldukları bilinmektedir (Turan, 2002: 55). 13 Haziran 1960 tarihli Milliyet Gazetesi'nde, “Mitinglerde altın toplandl. Sartyer'de ve Kemalpaşa'daki mitinglerde halk ziynet eşyasın hazineye teberru etti. Kampanya devam ediyor" başlıklı haberin devamında; "Sartyer'de dün milli İnkılap hareketini kutlamak için yapılan mitingde 22 yıllık evli bir kadın nikâh yüzü̈̆̈̈nü çıkartmış ve "Tek ziynet eşyam" diyerek Mal Müdürlüğ̈̈'ne teslim etmiştir. Mitinglerde bulunan 10 binden fazla Sartyerlinin bu harekete toplu olarak iştirak etmesi üzerine Mal Müdürü yüzükleri bugün teslim alacağını bildirmiştir" denilerek başlatılan kampanyaya halkın göstermiş olduğu büyük ilgiye dikkat çekilmiştir (Milliyet, 13.06.1960: 1). Bu kapsamda bağış kampanyası yarışının son süratle yurdun her yerine yayıldığı, vatandaşların kampanya için seferber olduğu, ziynet eşyalarını verdiği ve gazete vasitasıyla 107 kişinin de bağışta bulunduğu belirtilmiştir (Milliyet, 15.06.1960: 1).

Bağış kampanyası adı altında "27 Mayıs 1960 tarihli- Hâkimiyet Milletindir adlı hatıra paraları" da tedavüle çıkarılmıştır. MBK tarafından kabul edilerek yürürlüğe giren bir kanunla, 100 Milyon lira tutarında, 27 Mayıs İnkılabı Hatıra Paraları basılmas1 kabul edilmiştir (İnkılap, 05.12.1960, Y11: 1 Sayı:20). 27 Mayıs 1960 Askeri Darbesi sonrasında darbe anısına tedavüle çıkarılacak olan madenî 10 liralık hatıra paraları hakkında ilân metni şu şekildedir: "141 sayıl kanunun verdiği salahiyete müsteniden 31 Aralık 1960 tarihinden itibaren peyderpey tedavüle çıkarılacak olan 27 Mayıs inkılâbı hatıra parası madenî 10 liralıkların evsafi aşağıda gösterilmiştir. Mezkûr 10 liralıklar $34 \mathrm{~m} / \mathrm{m}$ kutrunda 15 gram ă̆ırlı̆̆ında olup 830 ayarında gümüsten imal edilmiştir. Kenarları, karanfil ve lâle motifleri arasında T. C. rumuzlar ile kenar çerçevesini iki müsavi klsma bölen kesik hatları ihtiva etmektedir. Paranin bir tarafindan 27 Mayıs inklâbımızı sembolize eden bir kompozisyon (Meş'ale, terazi, bayrak, süngü, kartal, çipa) bu kompozisyonun üstünde ışık huzmeleri saçan ay ylldiz, altında «27 Mayıs 1960» tarihi, çevrenin üst kenarında «HÂKIMIYYET MILLETINDIR» ibaresi alt kenarında defne ve meşe yapraklarından ibaret çelenk bulunmaktadır. Paranın diğer tarafinda orta yerde Atatürk'ün profil yüz portresi, çevrenin alt kenarında "On lira» yazısl, üst kenarında «Türkiye Cumhuriyeti» ibaresi mevcuttur. Hatıra paralar, paranın bir tarafi să̆dın sola veya soldan sağa çevrildiğinde diğer tarafi düz gözükecek şekilde basılmıştır." (T.C. Resmi Gazete, 30.12.1960, Sayı: 10694: 5).

Üstelik Güzel Sanatlar Akademisi ögrencileri tarafindan hazırlanan ve 25 liraya mal olan "Atatürk büstü" de buna dâhildir. Atatürk büstü satışlarından elde edilecek olan geliri hazineye yatırmayı kararlaştırmışlardır. Bu büstün 25 lira üstündeki satış gelirleri böylece devlete bağışlanmıştır (Turan, 2002: 55). Bir diğer uygulama ise, ambalajında "Milletçe El 
Ele: 27 Mayls 1960" yazılı sigaraların piyasaya sürülmesidir (Atılgan vd., 2015: 544). 27 May1s 1960 Askeri Darbesi sonrasinda propaganda materyali olarak kullanılanlar arasında pullar ve ilk gün zarfları da mevcuttur. Bu propaganda faaliyetlerine ek olarak, kamuoyunun heyecanı diri tutma adına "Hürriyet Mitingleri" de düzenlenmiştir. 8 Haziran 1960 tarihinde İstanbul'da Beyazıt ve Taksim Meydanlarında düzenlenen mitingler bunun göstergesidir. Konuya ilişkin haberlerin basında geniş yankı uyandırdığ 1 da bilinmektedir (İnce Erdoğan, 2017: 323). 9 Haziran 1960 tarihli Hürriyet Gazetesi’nde, “Hürriyet Bayramı: İstanbul dün coştu" başlığının devamında; ordu, gençlik ve halkın Beyazıt ve Taksim Meydanlarında ant içtiği, İstanbul'un birlik olup mitinge katılması ile birlikte verdiği desteğe dikkat çekilmiştir (Hürriyet，09.06.1960: 1). Görüldüğü üzere 27 Mayıs 1960 Askeri Darbe sonrası iktidarı ele alan MBK, hedef kitle üzerinde darbenin nasıl meşru k1lınacağı ve nasıl bir yöntem izlenmesi gerektiği sorunsalına propaganda girişimleri ile çözüm bulmaya çalışmıştır (Çelik, 2019: 94).

Sonuç olarak, 27 Mayıs 1960 Askeri Darbe sonrasında uygulanan propaganda faaliyetlerinin sosyal ve ekonomik alana nasıl yansımış olduğu ve uygulandığı görülmektedir. Böylelikle halktan toplanan yardımlarla darbeye destek aktarımı sağlanmıştır. MBK'nin siyasal süreç içerisinde yerini koruyabilmek için kamuoyu oluşturmada önemli bir faktör olan propaganda materyalleri aracılığıyla yeni düzenin benimsenmesi yönünde girişimlerde bulunduğu görülmüştür. Bu şekilde istenilen doğrultuda halkın düşüncelerinin biçimlendirilmesine de etki edilmiştir. Bir bitkinin toprağa ekilerek filizlenmesi gibi propagandanın bir tehdit unsuru oluşturma potansiyeli kullanmış; diğer taraftan fikrin hedef kitle üzerinde yayılıp kabul ettirilmesi sağlanmıştır. 27 Mayıs 1960 Askeri Darbesini meşrulaştırma diğer bir ifadeyle kamuoyunda haklı gösterme girişimlerinde propaganda yöntemlerinin aktif olarak kullanıldığ 1 ve başarı kazanıldığı da bilinen bir gerçektir. Dönemin karşı kaşıya kalmış olduğu 27 Mayıs 1960 Askeri Darbesini meşrulaştırma girişimlerinin materyallerini; kitle iletişim araçlarının toplum üzerindeki etkisinden faydalanılan radyo, broșürler, dergiler, kitaplar, dönemin gazete manşetleri, paralar, pullar, ilk gün zarfları, sigara paketlerinin yanı sıra yazı ve politik konuşmalar oluşturmuştur.

\section{Demokrat Parti (DP) Aleyhinde Başlatılan Linç Kampanyası}

Bir devletin diğer devletlere karşı gücünü ve yerini sağlamlaştırmak için almış olduğu önlemlerin tümüne "siyasi propaganda" denir (Başdoğan, 1960: 15). Dr. Hans Speier, siyasi propaganda için gerekli olan yöntemleri sırasıyla bozgunculuk, boyun eğdirme, işbirliği, fakirlik hissiyatı vermek ve panik yaratmak olarak açıklamıştır. En etkili siyasal propaganda, hedef kitleyi propagandacının kitleden beklediği şeyi yapması konusunda istekli hale getiren propagandadır (Özsoy, 2002: 210). Bunun tarihi örneği, 27 Mayıs 1960 Askeri Darbesi sonrası kaynaklarda bariz bir şekilde görülmektedir. Kitlelere yönelik basın ve basım yoluyla siyasi propaganda uygulanmış ve kamuoyunun etkilenmesi sağlanmıştır.

27 Mayıs 1960 Askeri Darbesinden sonra Kurmay Binbaşı Avni Elevli’nin kaleme aldığ1 "Hürriyet İçin 27 Mayıs 1960 Devrimi" adlı kitabında, "Sabıklar memlekette milli duyguları, milli heyecanlı, şeref, namus ve ahlak mefhumların kaldırmak için elinden geldiği kadar çalıştılar. Böylece muazzam bir para, eğlence, lüks ve sefahat hırsl yanında memlekette büyük bir zümrenin sefalet içinde yaşamasın sebebiyet verdiler... Bir taraftan da ilim adamlarına hakir görmeye ve cahillerle, dini alet eden yobazlara ön vermeye başladilar..." diyerek DP iktidarına yönelik birtakım suçlamalara yer verildiği görülmektedir (Elevli, 1960: 155). Bu dönemde yazılan bir diğer eser, Vecdi Bürün'ün "Şanlı Türk Ordusunun Zaferi Kansız Ihtilal" adlı eseridir. Eserde, "Devlet Parası" başlı̆̆ı altında Adnan Menderes ile ilgili olarak ağır ithamlarda bulunulmuştur: "Aydın vilayet merkezine $17 \mathrm{~km}$ mesafede bulunan 2500 dönümlük Çakırbeyli ilçesi için devlet kasasından 100 binlerce lira 
harcanarak 2 muazzam beton köprü inșa ettirilmiștir...” (Bürün, 1960: 127). Nimet Arzık'1n kaleme aldığı "Menderes 'i İpe Götürenler" adlı kitabında; “... Adı Adnan Menderes olmadan Adnan Ertekin'di... Bir milletin başına geçti... Memleketini kendine göre seviyordu, halkına "benim gibi bir adamı anlamıyorlar" diye hınç duya duya... Bilgisizdi, formasyonsuzdu, hümanizmasızdı. Memleketini seviyordu. Tipkı avucundaki kuşu bilmeden, sevgiden sıkarak boğan çocuk gibi...” (Arzık, 1960: 138-139). 27 Mayıs 1960 Askeri Darbesinin meşrulaş̧ırılması adına ileri sürülen birçok iddiaların yer aldığı kitaplar, genellikle ordu mensupları tarafından kaleme alınmıştır. Özellikle bu kitaplarda DP'lilere yönelik ağır suçlamaların ve toplum nezdinde değersizleştirilen yakıştırmaların yer aldığı örneklere bolca rastlanmaktadır. Böylelikle kamuoyunun oluşturulması için propaganda araçlarından olan kitaplar aracılığıyla destek aktarımı sağlanmaya çalışılmıştır (İnce Erdoğan, 2017: 317).

1960 yılında Başbakanlık Devlet Basımevi tarafından basılan "Ak Devrim” kitabında ise, 11 Haziran 1960 tarihli Vatan Gazetesi'nin "30 Milyon Iç̧inde 1500 Kişi” başlıklı yazı dikkat çekicidir. Oktay Akbal'ın yazısı ise şöyledir: "Dinleyin şu sözleri! İbretle, dehşetle dinleyin! Hem de Sayın Devlet Başkanımızın ă̆zından dinleyin: "Harbiyelilerin yürüyüşünden sonra ziyadesiyle telaşlanan sabıka hükümet adamları Çankaya'da toplanlyorlar. Aralarında Ankara Valisi Dilaver Argun da var. Durum müzakere ediliyor. Bazı tedbirler ileri sürülüyor. Celal Bayar 30 milyon insan arasinda 1500 kişinin yok edilmesinde hiçbir mahsur olmadı̆̆ını söylüyor. Bunları her ne pahasına olursa olsun imha etmelidir..." (Ak Devrim, 1960: 244-245). Bununla birlikte MBK tarafindan cesetlerin, yem makinalarında kıyılıp toz haline getirildiği belirtilmiştir (Akşam, 04.06.1960: 1). 27 Mayıs 1960 Askeri Darbesi sonrası siyasi alanda tehlikeli bir silah olarak kullanılan propagandanın gücü ve yıkıcı etkisi yadsınamaz büyüklükte olmuştur. DP ve idarecilerinin aleyhinde uygulanan korkunç ve sistemli propagandaya karşı, DP'lilerin gerekli tedbirlerin alınması noktasında yetersiz kalındığ1 görülmüştür (Burçak, 1976: 126-127).

15 Haziran 1960 tarihli Ulus Gazetesi'nde, DP'nin Türk ulusuna bıraktı̆̆ tek mirasın borç olduğu dile getirilmiştir. Ulaştırma hizmetleri alanındaki durum hususunda da Sitkı Ulay, "Demir, Deniz, Hava yollarının borcu milyarın çok üstünde! Ulay, yurtseverlere büyük acı vermekte olan bu duruma "Döviz kaçakçıll̆ğl, kolay ve çabuk zengin olmalar, kalkınma ismi verilerek ve rey avcılığı için milyonluk lüks inşaat, zümre hatırl, iltimas ve şuursuz idare sebep olmuştur" diyerek DP'nin Türkiye ekonomisinde büyük yaralar açtığı algısı dikkat çekicidir (Ulus, 15. 06. 1960: 1). Eskişehir Örfi İdare Komutanı Tuğgeneral Bedii Kireçtepe tarafindan "Ankara'da bütün hükümet erkânı ve Demokrat Parti başkanları yabancl memlekete kaçarken yakalanmışlardır. Beraberlerinde 12 uçak dolusu altın, mücevherat ve parayı kaçırmakta iken yakalandılar..." şeklinde yayınlanan tebliğ metni de dönemin propaganda algısını ortaya koymaktadır. (Eskişehir Örfi İdare Kumandanlığı Tarafından Yayınlanan Tebliğ, 27.05.1960). Ayrıca DP iktidar erkânları için bankalardan külliyetli paralar çektiklerini, Maliye Bakanı Hasan Polatkan'ın Ankara Sigortası'ndan zimmetinde 4 milyon liradan fazla para çekip zimmetine geçirdiği tespit edildiği haberleri de dönemin gazete manşetlerinde yer almıştır (Hürriyet, 03.06.1960: 1).

Görüldüğü üzere, 27 Mayıs 1960 Askeri Darbesi sonrası bu ve buna benzer haberler, iddialar, iftiralar, şayialar ve yayınlarla kamuoyunun fikren hazırlanması sağlanmıştır. Propaganda kampanyaları ile kitlenin dikkati istenilen yöne çevrilmiş ve böylelikle yaygın bir hale getirilmiştir. Topum üzerinde gerekli etkiyi yaratabilmek için propaganda faaliyetleri, bir bütün halinde yürütülmüştür. Ancak dönemin propaganda algısını idrak edebilmek için dönemin kitap, dergi ve gazetelerinde darbeyi ve onu gerçekleştirenlerin haklı çıkma girişimleri ve meşruiyetinin sağlandığı gerçeği yadsınamaz. 


\section{5.İnfaz Yeri Yassıada Ve Propaganda Broşürü}

MBK Genel Kurulu toplantı sonrasında DP üyelerinin Yassiada'da yargılanmasına karar verilmiştir (Hürriyet, 20 Temmuz 1960: 1). Böylelikle Yassıada'da duruşmalar yapılmış ve Yassiada, idam kararlarının infaz yeri olmuştur (Sabah Postas1, 17 Ekim 1960:1). İnfaz yeri olan Yassıada'da yargılanacak olan DP'lilere “düşük” yakıştırması yapılmıştır. Ayrıca kararnameler tutuklu bulunan DP'lilere, tebliğ edildiğinde idam talebi ile yargılanacaklarını öğrenenlerinde fenalık geçirmişlerdir (Demokrat İzmir, 13.10.1960: 1). Yargılamalar için hazırlıkların tamamlanmasının ardından Dolmabahçe'deki İrtibat Bürosunda son olarak bir basın toplantısı yapılmıștır. Duruşmaları takip etmek üzere yurdun dört bir tarafından gelen yerli ve yabancı basın mensupları, Fenerbahçe vapuru ile Yassıada'ya tatbikat amacıyla götürülmüştür (Ulus, 12.10.1960: 1).

Bir darbe mahkemesi olarak kurulan Yassiada Mahkemesi'nde alınan kararların amacı, yapılan darbeyi kamuoyunun gözünde haklı gösterebilmekti (Naskali, 2016: 174). Bu nedenle MBK, DP üyelerinin yargılama hususunda özenle çalışmıştır. Dönemin yayınlarından da anlaşılacağı üzere DP üyeleri kinayeli, alaycı ve sert bir şekilde eleştirilmişlerdir. Türk siyasi hayatında önemli bir yere sahip olan 27 Mayıs 1960 Askeri Darbesi adına yazılmış propaganda broşürü Yassıada Broşürü, bunun tarihi bir örneğidir. 35 sayfadan oluşan broşür, 1960 yılının Ekim ayında MBK İrtibat Bürosu tarafından yayınlanmıştır. Yayınlanan broşürde; “İnkılabın Sebepleri, Inkılabın Gerekçesi, 27 Mayıs'ın Manası, Yassıada'nın Manası, Düşük İktidar Mensupları Neden Yargllanmaktadır?, Yargılanacakları Suçlar, Düşük Cumhurbaşkanı Celal Bayar, Düşük Başbakan Adnan Menderes, Düşük Bakanların D.P. Milletvekillerinin Topluca Ve Hadisesine Göre Ferden Mesul Oldukları Suçlar" başlıkları büyük punto ile yer verilirken "Lütfen Aşağıdaki Gibi Hareket Ediniz" başlığının alt başlığında ise sırasıyla; müzede, vapurda, adada, kötü havalarda İstanbul'a dönüş mümkün olmadığı zaman hareket tarzı, önemli hususları bir daha hatırlayınız şeklinde kurallardan oluşan talimat dizilimine yer verilmiştir. Son olarak broşürde, "Yassıada'nın Tarihçesi" ne yer verilerek bitirilmiştir. Kısaca yer yer fotoğraflarla 27 Mayis 1960 Askeri Darbesi tasvir edilmiştir. 27 Mayıs 1960 Askeri Darbesinin neden yapıldığını, o dönemin atmosferini, niçin bu duruma gelindiğini, DP üyelerinin suçlarını ve son olarak Yassıada'nın niçin oluşturulduğu ve ne anlam ifade ettiği açıklanmıştır (Yassıada Broşürü, 1960).

Darbe sonrası DP üyelerinin yargılanması için götürüldükleri yer olan ve burada kurulan özel mahkemenin ne anlam ifade ettiği "Yassıada'nın manası" başlı̆̆ı altında şu şekilde betimlenmiştir: "Yasslada, Atatürk'ten sonra nüksetmiş şarklıllk zihniyetinin, gene Atatürk ülkücüleri tarafindan kabzedildiği yerdir. Yassiada, 1950'den başlayıp, 19 Mayls 1919'a kadar geri gitmek isteyenlerin azgın başlarına geçirilmiş bir kanun kemendidir. Yassıada, yalancı bir evliya edası ile Anayasayı çiğneyerek memleketi fethe çıkan din istismarcıların hüsran ile neticelenen fütuhatıdır. Yassıada, devleti, çiftlik kâhyası ve bir mirasyedi gibi idare zihniyetine indirilmiş sembolik bir şamardir. Yassiada, iktidar zevki, memleket sevgisinin, partizan düşüncelerini memleket menfaatlerinin üstünde tutan demagog politikacının ibret sahnesidir. Yassıada, seçmenlere reylerinin sahipliğini, milletvekillerine, Meclis'te kaldıracağı park parmağının şuur ve idrakini sağlamıştır. Netice olarak, Yassıada, 27 Mayıs İnkılâbımızın, onu diğer bütün ihtilallerin üstüne çıkaran hukuki bir belgesi ve ikinci Cumhuriyet mutlu yıllarının kararmayacak fecri olacaktır." (Yassıada Broşürü, 1960: 21).

Ayrıca Yassıada broşüründe DP üyelerinin sorumlu oldukları suçlar ise maddeler halinde aşağıdaki şekliyle açıklanmıştır: 
- "Anayasaya aykırl fiil ve hareketler ve 15 kişilik Meclis Tahkikat Komisyonu teşkili ile bu komisyonun faaliyetine müteallik hadiseler. Bu kısım giriş faslında izah edildiği şekilde Türk Ceza Kanunu'nun (TCK) 146'ncı maddesine mümas bir suç teşkil eder mahiyettedir.

- Topluca veya teker teker görevlerini kötüye kullanmak suretiyle, TCK'nın 240'ncı maddesine mümas harekette bulunmak ve nüfuzlarını kötüye kullanmak suretiyle kredi ve döviz suiistimalleri suçların işlemek ve muhtelif yollarla sair menfaatler temin etmek. Bu kısma da Ceza Kanunu'nun suistimal, zimmet, rüşvet ve irtikâp suçları girer ki, hadiselere göre, tespit ve şahıslara göre tayini mahkemenin vazifesi cümlesindendir.

- 28 Nisan 1960'dan 27 Mayls 1960'a kadar geçen devre içinde vukua gelen cinayet hadiseleri. Bu hadiselere iştirak nispetlerine göre katil suçundan, vazifeyi suiistimal suçuna kadar muhtelif derecelerdeki suçları işlemiş bulunmaktadirlar. Tahkikat sonunda bu suçlara iştirak edenlere suçluluk derecelerini tespit ve duruşma sonunda da cezalandırmak kabil olacaktır.

- Muhalefete karşı Anayasaya mugayir bir şekilde girişilen ve memleket ölçüsünde hadiseler yaratan münferit vakalar: Uşak, Topkapı, Zile, Geyikli, Turgutlu, Kayseri ve Yeşilhisar olaylart. Bu olaylarda suçları bulunan şahıslar ayrı ayrı tahkikatlar sonunda tespit edilerek iştirak nispetleri ve suçluluk derecelerine göre cezalandırlacaktır.

- 6-7 Eylül hadiseleri.

- 1957 Seçim yolsuzlukları.

- Dinin partizan maksatla da istismarı.

- Vatan Cephesi teşkili suretiyle Türk vatandaşlarının ikiye ayrlmasına matuf fiil ve hareketler. Bu arada Vatan Cephesi mensuplarının ve bunlara yakın güruhların silahlandırıldıkları husus sübuta erecek olursa, düşük iktidara mensup Vatan Cephesi kurucular ve bu hareketlerin tertipçileri eylemlerine uyan TCK'nın 149'ncu maddesine göre tecziye edilmek üzere yargılanacaklardır." (Yassıada Broşürü, 1960: 29-30).

11 Ekim 1960 tarihli Hürriyet Gazetesi'nde, "MBK, düşüklerin suçu ile ilgili kitap yayınladı" şeklinde sözü edilen bu broşür hakkında bilgi verilmektedir. Ayrıca "kitapta istenen cezalar da yer alyyor" denilerek belirtilmiştir (Hürriyet, 11.10.1960: 1).

Son olarak MBK tarafından yayınlanan broşür, organize edilen Yassıada yargılamalarının meşruiyetini sağlamak ve kamuoyuna bu durumu açıklamak için propaganda aracı olarak kullanılmıştır. Böylelikle toplum üzerinde istenilen düşüncelerin rahat bir şekilde topluma empoze edileceği bir ortam oluşturulmuştur. Yapılan tüm bu propaganda faaliyetleri, hali hazır heyecanları tahrik etmek için kullanılmıştır. 27 Mayıs 1960 Askeri Darbesinin haklılığının ispatının sağlanması için de darbeye kurban verilmesi gerekli görülmüştür. $\mathrm{Bu}$ sebeple dönemin Başbakanı Adnan Menderes, Dışişleri Bakanı Fatin Rüştü Zorlu ve Maliye Bakanı Hasan Polatkan idam edilmişlerdir. Fakat hukuka ve hukukun işleyişine aykırı kurulmuş olan Yassiada Mahkemesi, yargılama sürecinde yapılan muameleler ve verilen kararlar hiçbir şekilde adaletle örtüşmemiş, tarihte kara bir leke olarak kalmıştır. 


\section{Demokrat Parti'nin (DP) Kapatılması}

27 Mayıs 1960 Askeri Darbesinin siyasal katılma ve örgütlenme üzerindeki ilk etkisi, DP'nin kapatılması olmuştur (Mazıcı, 1989: 119). Alınan bu karar, MBK'nin çıkardığı 13 Numaralı tebliğ gereğince şu şekilde belirtilmiştir:

- Biz vatandaşları birbirine düşürecek bir kardeş kavgasını önlemek için bu işe giriştik. Vatandaşların birbirlerine karşı vatandaşlı hak ve hukuklarına riayet etmelerini, birbirlerini sevip saymaların, hangi partiden olursa olsun birbirlerine sevgi saygl göstermelerini istiyorum.

- Yeni Anayasanin hazırlanmasi vazifesi Sayın Rektör Siddık Sami Onar'in başkanlığındaki profesörlerden mürekkep yüksek bir ilim ve hukuk heyetine tevdi edilmiştir.

- Yeni Anayasa ilân ve tatbik mevkiine girinceye kadar bütün siyasî partilerin faaliyetini menediyorum.

- Aksi hareketleri çok şiddetle cezalandıracağım.

- Vatandaşlarımın verilen tebliğlere riayet etmelerini bilhassa, rica ederim (T.C. Resmi Gazete, 30.05.1960, Say1: 10515: 3).

Kısaca 27 Mayıs 1960 Askeri Darbe sonrası, Cumhuriyet Halk Partisi (CHP) dışında kalan siyasal partilerin bu süreçte nasıl yer alacakları darbeyi gerçekleştiren subaylar tarafindan belirlenmiştir. Hangi parti olursa olsun 27 Mayıs felsefesinin dışına çıkmaları ve bu hareketin aleyhine propaganda yapmaları yasaklanmıştır (Mazıcı, 1989: 238).

7 Ocak 1946'da Celâl Bayar, Adnan Menderes, Refik Koraltan ve Fuat Köprülü tarafından kurulan DP'nin, darbe sonrası kapatılmasına ilişkin dava, Ankara 4. Asliye Hukuk Mahkemesi'nde görülmüştür. Bir DP'li tarafından açılan dava sonrası verilen kararla partinin sonu belirlenmiştir. Partinin kapatılma gerekçesi olarak, DP'nin kongre yapmama ve gayeden ayrılması görülmüştür (Milliyet, 30.09.1960: 1). DP'nin kapanış süreci 3 Ekim 1960 tarihli Akis Dergisi'nde, davanın tek hâkimli olarak görüldüğü, saat 10.03'ü gösterdiği sıralarda başlayan duruşmanın tamamı tamamına 14 dakika sürdüğünü, 14 küsur senelik maziye sahip bir partinin siyasî tarihin karanlıklarına nasıl gömüldüğü işlenmiştir (Akis, 03.10.1960: 16-17). Ayrıca DP'nin kapatılma kararının bir müteahhidin açtığı dava üzerine verildiği, durumun Adnan Menderes'e Yassiada'da tebliğ olunduğu, üstelik partinin bütün mallarının hazineye intikal ettiği, 15 yıllık bir faaliyetten sonra DP'nin Ankara 4. Asliye Hukuk Mahkemesi kararı ile Cemiyetler kanunu aykırı faaliyette bulunduğu için kapatıldığ belirtilmiştir. Ankara 4. Asliye Hukuk Mahkemesi'nin yazılı kararı Yassıada'da bundan DP Genel Başkanı'na tebliğ edildikten sonra 15 gün zarfında Adnan Menderes, kararın temyizini isteyebilecekti. Ankara 4. Asliye Hukuk Mahkemesi'nde DP'nin kapatılmasına dair konuyu gündeme getiren ve davanın açılmasını sağlayan kişi ise, "Mustafa Geygel" olmuştur (Vatandaş, 30.09. 1960: 1). Karar verildikten sonra bu hususta Akis Dergisi muhabirinin Mustafa Geygel ile yaptı̆̆ mülakat ise dikkat çekicidir. Geygel için, "DP'yi Kapattıran Adam!" başlığı atılmış; devamında "Bir isim bir günde memleket çapında şöhrete kavuşmuş bulunuyor. Bu, DP'nin kapatılması için 27 Mayıs'tan sonra dava açan Mustafa Geygel adlı vatandaştır. Kimdir bu vatandaş? Nasıl bir düşünceyle ve hukuk anlaylşlyla D.P. nin kapatılması için teşebbüse geçmiştir? Demokratlığı nereden gelmiştir? Bir 1957 Demokratı olan davact, D.P. bütün antidemokratik kanunları çıkardıktan sonra bu siyasi teşekküle girmiştir. Daha garibi, partisinin kongre yapmaması karşısında 27 Mayısa kadar bir itiraz sesi yükselttiğini duyan da olmamıştır. Mümtaz 1957 Demokratı sâdece sesini çıkarmamakla yetinmemiş, partisinden sessizce istifayı da hiç hatırına getirmemiştir. Ancak D.P. iktidarı 
devrildikten sonradır ki mahkemeye koşan Geygel'in çizgileri AKiS muhabirine anlattıkları okunduğunda gözlerin önünde tam bir açıklıkla çizilmiş olacaktır. Sanırız ki D.P. ile kaderin istihzası hiç bir zaman bu kadar açık şekilde belirmemiştir ve kolay kolay da belirmeyecektir!" denilmiştir. Mülakatta ayrıca Geygel'in hayat hikâyesi, siyasete atılması, DP'ye girişi, DP'den ayrılışı ve DP'nin kapatılması için açtığı dava aktarılmıştır (Akis, 03.10.1960: 14-15).

Dâvacı Mustafa Geygel'in vekili olan Avukat Cemal Özbey'in 1961 yılında basılan "Demokrat Parti'yi Nasıl Kapattırdım" adlı eseri dikkat çekicidir. DP'nin akıbeti üzerine ayrıntılı bir şekilde yer vererek döneme kaynaklık eden Özbey’in eserinin önsözünde, "memleketimizin mukadderatı üzerinde 15 yll mühim roller oynayan bir siyasi partinin kısaca hayat hikâyesidir, ibret dersleri ile dolu bu hikâyeden şahsî, ahlâkî ve siyasi dersler almak mümkündür..." denilmektedir. Öncelikle eserde, kronolojik bir biçimde dava ve duruşmanın evreleri tek tek işlenmiştir. Devamında ise, DP'nin kapatılması kararına ilişkin belli başlı siyasetçilerin yorumlarına yer verilmiştir.

30 Eylül 1960 tarihli çeşitli İstanbul ve Ankara gazetelerinden alınmış siyasetçilerin sözleri ise şu şekilde aktarılmıştır: CHP Genel Başkanı İsmet İnönü: "Karar Adalete aittir - Benim için söylenecek bir şey yoktur" demiştir. Cumhuriyetçi Köylü Millet Partisi (CKMP) Genel İdare Kurulu üyesi Fuat Arna, "Maalesef yolu kendileri çizdiler ve kendi kazdıkları kuyuya kendileri düşüler. Fakat şunu bilhassa söyleyeyim ki, millet hizmetine girmiş olan hiç bir siyasî teşekkülün böyle bir akıbete maruz kalmasından memnuniyet duymayız" sözleriyle ifade etmiştir. Falih Rıfkı Atay, "Demokrat Parti bizim siyasî talihimizde ancak meşrutiyetin Hürriyet ve İtilâf Partisini hatırlatmakta idi. Onun dağgllı̧ı gibi, bunun da kapanışı iç politikamızın gelişmeleri için faydalı olacaktır. Yalnız hortlamamasma dikkat etmeliyiz" şekliyle dile getirmiş̧ir. Ankara Üniversitesi Rektörü Suut Kemal Yetkin ise, "Vazifesini ihmal eden ve kötüye kullanan her siyasî teşekkülün akıbeti budur" diyerek DP'nin kapatılması kararının yerinde bir karar olduğunu vurgulamıştır.

Eserde, DP'nin kapatılmasına dair iç basının nasıl bir tutum sergilediği de ele alınmıştır. Bunun birkaç örneği olarak; 30 Eylül 1960 tarihli Cumhuriyet Gazetesi'nde, "Demokrat Parti, Mahkeme kararı ile dün kapatıldı. Partinin siyasî hayatı 15 yll, 4 ay, 15 gün, 1 saat, 35 dakika sürdü” başlığının devamında “... Böylelikle 15 sene, 4 ay, 15 gün, 1 saat, 35 dakika sonra tarihi bir karar alınmış ve D.P. resmen kapatılmış ve tarihe mal olmuştur. Yargıç Raif Elmadağgl, mübaşir Hasan Tolun, dâvacı Mustafa Geygel, avukatı Cemâl Özbey ve düşük D.P. Genel başkanının avukatı Kemal Yılmaz bu kararla tarihe geçmiş bulunuyorlardl" denilmektedir. 30 Eylül 1960 Hürriyet Gazetesi'nde Geygel'in ifadesi ise dikkat çekicidir. "...D.P. nin kapatılması için dâva açan partili Geygel: "D.P. den zarar görmedim” demiştir. 1 Ekim 1960 tarihli Ulus Gazetesi'nden, Yakup Kadri Karaosmanoğlu yazısında, "Demokrat Parti, iki günden beri, tıpkı «müflis» bir şirket gibi mahkeme kararı ile kapatılmış veya feshedilmiş bulunuyor. Memlekete gerçek demokrasiyi, fikir ve vicdan hürriyetini, teminatlı adaleti getirmek, kısaca bütün manası ile bir hukuk devleti kurmak için teşekkül eden bir siyasi partinin on yıllık bir iktidar sonunda bu hale düşmesi pek acıkl bir akıbettir... Evet, Demokrat Parti artık tarihe geçmiştir..." denilmektedir. 4 Ekim 1960 tarihli Sır Mecmuası'nda Cihad Baban, “Demokrat Parti Kapandı! Vatan sağ olsun! ... Evet, Demokrat Parti kapandı! Gerisinde ümitlerden, ideallerden örülü hatıraları da, devrildiği çukura beraber sürükleyerek ve fena bir isim birakarak tarihe mal olacakttr. Dünyada bir milleti böylesine aldatmış, en temiz duyguları böylesine istismar etmiş bir başka teşekkül, bir başka hareket görülmemiştir... Demokrat Partinin bu hali, yalanı, sahtekârlığı, iftirayı politika vasitasi olarak kullanmak isteyen, her partideki insanlara ibret olmalıdır..." şeklinde ifade etmiştir. 3 Ekim 1960 tarihli Kim Mecmuası'nda, DP'nin kapatılması kararı, 
“... Böylece, Türkiye’de ilk defa iktidarda bulunmuş bir parti, adaletin hükmü ile tarihe karışmış oluyordu" şeklinde işlenmiştir.

Özbey eserinde, DP'nin tarihçesine de kısa bir yer vermiş; 27 Mayıs 1960 Askeri Darbe sonrası DP'nin akıbetine değinmiştir. Eserde siyasi yaşamına bir DP'li olarak başlamışsa da, Belediye seçimlerinde Malatya'nın bir mahallesinin sandık kurulu başkanı olduğu sırada parti ile arasının neden açıldığını ve bu partiden niçin ayrıldığını belirtmiştir. Parti faaliyetlerine ise, Hürriyet Partisi (HP) Malatya teşkilâtında yer alarak devam etmiştir. Ayrıca Özbey, 28 Nisan ve 27 Mayıs 1960 tarihlerinde yapılan mitinglere katıldığını ve iktidara karşı en iyi muhalif partisi olarak gördüğü CHP'ye 9 Mayıs 1960'da kaydolduğunu belirtmiştir. 27 Mayıs günü sabahı duyduğu tatlı heyecanı ve siyasi kanaatini ise şu şekilde dile getirmiştir: “... Bence asıl mühim olan 27 Mayıs inkılâbını yapmaktan ziyade bu inkılâbı tamamlamak ve iktidarl asıl sahibi bulunan millete iade eylemek ve memleketi bir an evvel huzura kavuşturmaktır. Milli Birlik Komitesinin bunu yapacağından da kat'i olarak emin bulunmaktayım." Ardından CHP, CKMP ve yeni kurulacak partiler hakkındaki kanaat ve tahminlerini dile getirmiştir.

Özbey'in DP'nin kapatılması girişimine karşılık; 2 Eylül 1960'da Adnan Menderes, "Partinin kapanmaması hususunda bir müdafaada bulunacak değilim. Bilâkis kapanmasının bu günün şartları bakımından doğru olacağı kanaatindeyim" diyerek partinin kapatılması kararını yerinde bulmuştur. Son olarak, eserin yazarı olan Avukat Cemâl Özbey'in ve Müvekkili Mustafa Geygel'in özgeçmişine de kısaca yer verilerek bitirilmiştir.

Böylelikle eser üzerinden dönemin tahlil edilmesi sağlanmış ve DP'nin nasıl noktalandığı ana hatlarıyla değerlendirilmeye çalışılmıştır. 27 Mayıs 1960 Askeri Darbesi sonrasında yazılmış olan bu eser, dönemin propaganda algısını idrak edebilmek için okunması gereken kaynaklardandır. Görüldüğü üzere etkili propaganda aracı olarak kullanılan kitaplar, okuyucu için genel bir tablo çizmesi açısından önemlidir.

\section{Sonuç}

27 Mayıs 1960 Askeri Darbe sonras1, DP iktidarına son verilmiş ve askeri yönetim kurulmuştur. Kurulan yönetim ilk günden itibaren askeri cunta adı altında faaliyetlerde bulunmuştur. $\mathrm{Bu}$ faaliyetlerde ilk olarak, DP idaresi ve üyeleri üzerinde uygulanmıştır. Zihnen ve psikolojik olarak DP'nin yıkımına yönelik algı, toplum nazarında oluşturulmak istenmiştir.

MBK ise, idaresini devam ettirebilmesi adına dönemin propaganda kaynaklarından yararlanmıştır. Propaganda kaynaklarından belli başlı olanları ise; resim, broşürler, dergiler, dönemin gazete manşetleri ve kitaplarıdır. Ayrıca yönetimin meşruiyetini sağlanmak adına MBK, özellikle darbeyi gerçekleştiren Türk milleti ibaresini sürekli olarak yinelemiştir. 1961 Anayasası'nın başlangıcında yer alan "devrimi yapan Türk milleti" cümlesi bunun göstergesidir. Bu kapsamda askerler, darbeye hukukî bir zemin oluşturmuştur. Fakat 27 Mayıs 1960 Askeri Darbesini ordu mensuplarından oluşan bir grup cunta gerçekleştirmiştir. Böylelikle 27 Mayıs 1960 Askeri Darbesi öncesi ve sonrası yapılan propagandalarla, DP iktidarının sonu getirilmiştir. 27 Mayıs 1960 Askeri Darbesi ile iktidardan uzaklaştırılan DP, 29 Eylül 1960 tarihinde Asliye Hukuk Mahkemesi’nce görülen dava sonucunda kapatılmıştır.

27 Mayıs 1960 Askeri Darbesi sonrasında MBK, 27 Mayıs'ın benimsenmesi, ülkenin her yerinde nüfuz sahibi olabilmesi ve idaresinin kalıcıllğı için birtakım propaganda faaliyetlerine girişmiştir. MBK eylemleri bununla da sınırlı kalmamış; DP yöneticilerinin yargılanması için MBK tarafindan Yassıada'da özel bir askeri mahkeme oluşturulmuştur. Mahkemece, DP ve üyelerine kesin hükümler giydirilmiştir. Çünkü DP iktidarı kurucuları yargılanmazsa, yapılan darbe gayrimeşru bir hal alacaktı. Böylelikle darbe meşru kılınmış; 
darbeye zemin hazırlayan ve ülkeyi çıkmaza sürükleyen DP iktidarı, gayrimeşru duruma düşürülmüştür. Çalışmamızın temel kaynağını teşkil eden 27 Mayıs 1960 Askeri Darbesi sonrası MBK ve propagandaya dâhil olan tüm araçların amacını gerçekleştirmek adına mübah kılınarak DP iktidarına karşı nasıl kullanıldığı görülmüştür. Böylelikle propaganda sanatının işlenip halka sunulması ve halkta cereyan eden cunta görünümlü darbenin yansımaları, DP sonunu getiren propaganda faaliyetleri ele alınmıştır.

Sonuç olarak; Yassıada'da yapılan yargılamalar ile darbenin meşruluğu sağlanmıştır. Yassıada Mahkemeleri'nde tutuklu bulunanlardan Türkiye Cumhuriyeti'nin Başbakanlığını yapmış Adnan Menderes, Dışişleri Bakanı Fatin Rüştü Zorlu ve Maliye Bakanı Hasan Polatkan'ın idam edilmiş olması bunun bir göstergesidir. 27 Mayıs 1960 Askeri Darbesini meşrulaştırmayı amaçlayan Yassıada davaları ve yargılamaları, yargının tarafsızlığını yitirip siyasallaştığı utanç verici bir olay olarak tarihteki yerini almıştır. Yakın dönemde görülen Ergenekon-Balyoz davaları ve yargılamaları, Yassıada davaları ve yargılamaları gibi iktidarın hukuk mekanizması üzerinde baskın bir güç olduğu, idari yargıda yürütmenin emrine girdiği benzer bir yargılama olmuştur. 


\section{Kaynakça}

\section{Arşiv Belgeleri}

Başkanlık Cumhuriyet Arşivi (BCA) 30-1-0-0/1-10-2, 08.07.1960.

Başkanlık Cumhuriyet Arşivi (BCA) 30-18-1-2/155-1-1, 30.05.1960.

\section{Gazete ve Süreli Yayınlar}

T.C. Resmi Gazete, Sayı: 10515, 30.05.1960.

T.C. Resmî Gazete, Sayı: 10525, 14.06.1960.

T.C. Resmi Gazete, Sayı: 10694, 30.12.1960.

Akis

Akşam

Cumhuriyet

Demokrat İzmir

Dünya

Hürriyet

İnkılap

Kim

Milliyet

Sabah Postası

Ulus

Vatan

Vatandaş

Yeni Asır

\section{Kitap, Makale ve Tezler}

ARZIK, N. (1960). Menderes 'i İpe Götürenler. Ankara: Kurtuluş Matbaası.

AK DEVRIM, (1960). Ankara: Başbakanlık Devlet Basımevi.

ALTUĞ, K. (1991). 27 Mayıs'tan 12 Mart'a. İstanbul: Yılmaz Yayınları.

ATILGAN, G. Vd. (2015). Osmanlı'dan Günümüze Türkiye'de Siyasal Hayat. İstanbul: Yordam Kitap.

AKŞìN, S. (2009). Ana Çizgileriyle Türkiye'nin Yakın Tarihi 1789-1980. Ankara: İmaj Yayınevi.

AHMAD, F. (1995). Modern Türkiye’nin Oluşumu. (Çev. Yavuz Alogan). İstanbul: Sarmal Yayınevi.

AHMAD, F. (2006). Bir Kimlik Peşinde Türkiye. (Çev. Sedat Cem Karadeli). İstanbul: İstanbul Bilgi Üniversitesi Yayınları.

ALKAN, M.Ö. (2017). Osmanlı'dan Günümüze Darbeler. İstanbul: Tarih Vakfi Yurt Yayınları. 
AYDIN, S. ve TAŞKIN, Y. (2014). 1960 tan Günümüze Türkiye Tarihi. İstanbul: İletişim Yayınları.

BAŞDOĞAN, F. (1960). Propaganda. Ankara: Kara Kuvvetleri Kumandanlığı Yayınları.

BÜRÜN, V. (1960). Şanlı Türk Ordusunun Zaferi, Kansız Ihtilal. İstanbul: Ekicigil Matbaası. BURÇAK, R. S. (1976). Yassiada ve Öncesi. Ankara: Çam Matbaası.

ÇELIK, F. (2019). 1960 Askeri Darbesinde Kamuoyu Oluşturma Projesi: Propaganda. Yayımlanmamış Yüksek Lisans Tezi, Aydın: Adnan Menderes Üniversitesi Sosyal Bilimler Enstitüsü.

DEMİRER, M. A. (2012). 27 Mayıs Masallar ve Gerçekler. İstanbul: Toplumsal Yayıncılık.

DEMIREL, T. (2011). Türkiye'nin Uzun On Ylll: Demokrat Parti Ikktidarl ve 27 Mayls Darbesi, İstanbul: İstanbul Bilgi Üniversitesi Yayınları.

DAVER, B. (1964). Türk Üniversite Öğrencileri ve Siyaset. Ankara Üniversitesi Siyasal Bilgiler Fakültesi Dergisi, C.19, S.3, s.37-46.

ESKISSEHIR ÖRFİ IDARE KUMANDANLIĞI TARAFINDAN YAYINLANAN TEBLİĞ. 27 May1s 1960.

ELEVLİ, A. (1960). Hürriyet İçin 27 Mayıs 1960 Devrimi. Ankara: Yeni Desen Matbaası.

Ed. ERSOY, T. ve ÇETINBAŞ, H. (2010). Resmi Tarih Tartışmaları 9, 27 Mayıs: Bir Darbenin Anatomisi. Ankara: Özgür Üniversite Yayınevi.

$\begin{array}{llllll}\text { ECEVIT, } & \text { B.(1960) } & \text { MBK ve Görüş Ayrllıklar1. } & 19.10 .1960 .\end{array}$ http://ecevityazilari.org/items/show/1262, Erişim Tarihi: 06.02.2021.

GÜRSOY NASKALİ, E. (2016). (Demokrat Parti; 27 Mayıs Devrimi, İnkılâp, İhtilâl, Darbe veya Ayaklanması) "Yassıada Mahkemesi Anayasayı İhlal Davası". Adnan Menderes Demokrasi Platformu Dergisi, s.174-181.

İNCE ERDOĞAN, D. (Mayıs, 2017). Propaganda: 27 Mayıs Darbesini Meşrulaştırma Çalışmaları. Uluslararası Darbe Sempozyumu, Aydın: Adnan Menderes Üniversitesi Yayınları, s.307-328.

KOÇAK, C. (2017). Darbeler Tarihi, 3. Baskı, İstanbul: Timaş Yayınları.

KARAVELIOĞLU, K. (2007). Bir Devrim İki Darbe: 27 Mayls - 12 Mart -12 Eylül, İstanbul: Gürer Yayınları.

MAZICI, N. (1989). Türkiye'de Askeri Darbeler ve Sivil Rejime Etkileri. İstanbul: Gür Yayınları.

ÖZSOY, O. (2002). Türkiye'de Seçmen Davranışları ve Etkin Propaganda. İstanbul: Alfa Yayınları.

ÖZBEY, C. (1961). Demokrat Parti'yi Nasıl Kapattırdım. Ankara: Emek Basım.

ÖZDAĞ, Ü. (1997). Menderes Döneminde Ordu-Siyaset İlişkileri ve 27 Mayıs İhtilali. İstanbul: Boyut Kitapları.

TARHAN, N. (2017). Anne, "Darbe” Ne Demek?. İstanbul: Timaş Yayınları.

TAYLAK, M. (1977). 27 Mayıs ve Türkeş. Ankara: Ayyıldız Matbaası. 
TOKGÖZ, O. (2010). Seçimler, Siyasal Reklamlar ve Siyasal İletişim. Ankara: İmge Kitabevi Yayınları.

TURAN, Ş. (2002). Türk Devrim Tarihi V Çăgdaşlık Yolunda Yeni Türkiye (27 Mayls 1960 12 Eylül 1980). Ankara: Bilgi Yayınevi.

TÜRKEŞ, A. Vd.(1964). Bazı Gerçekler (Savunmalar). İstanbul: Anıl Yayınevi.

YASSIADA BROŞÜRÜ. (Ekim-1960). İstanbul: T.C. Milli Birlik Komitesi İrtibat Bürosu. 


\section{EKLER:}

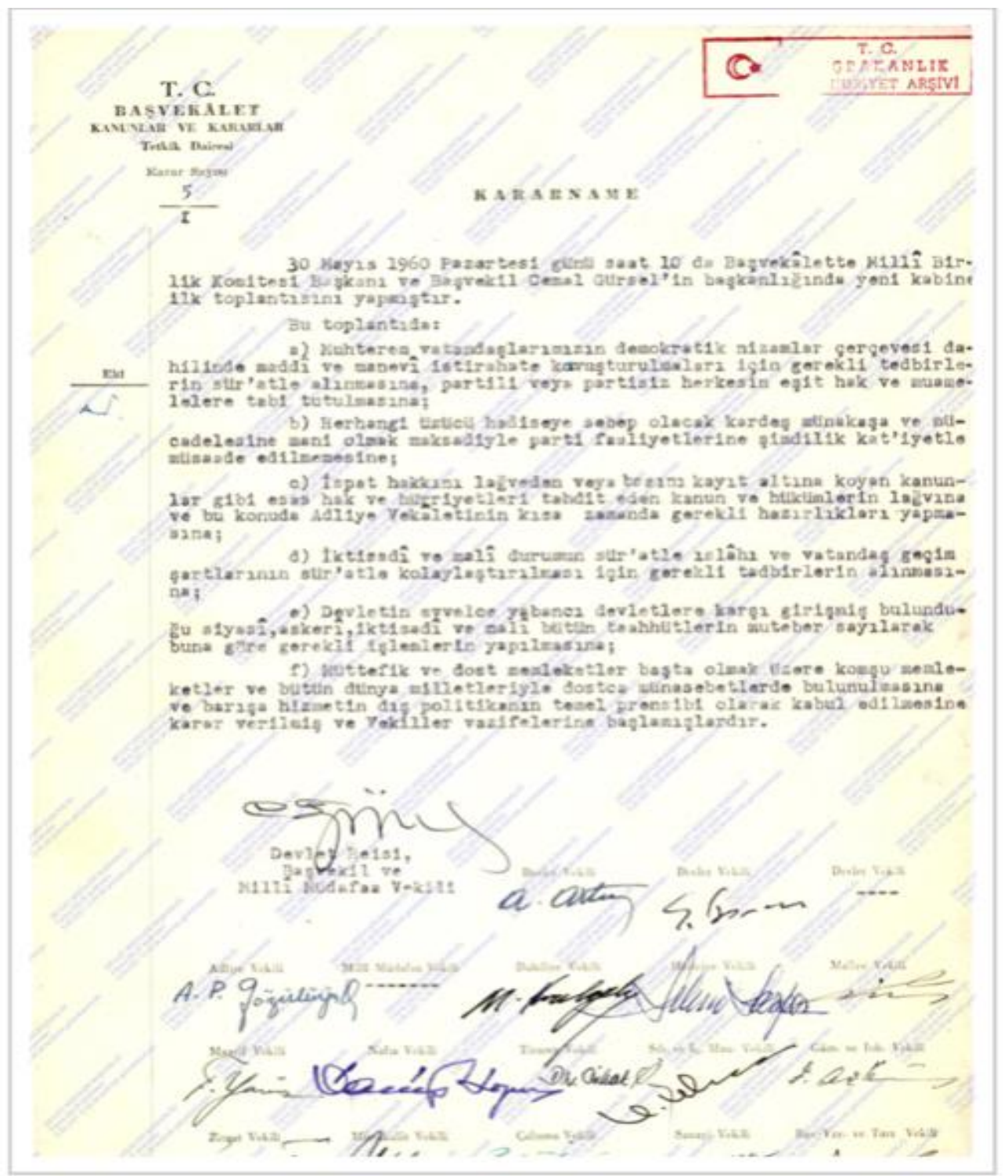

Ek 1: 30.05.1960 Pazartesi günü MBK Başkanı ve Başvekil Cemal Gürsel'in başkanlığında ilk toplantısını yapan yeni kabinenin alacağı tedbirleri gösteren beyanları (Başkanlık Cumhuriyet Arşivi (BCA), 30-18-1-2/155-1-1, 30.05.1960) 


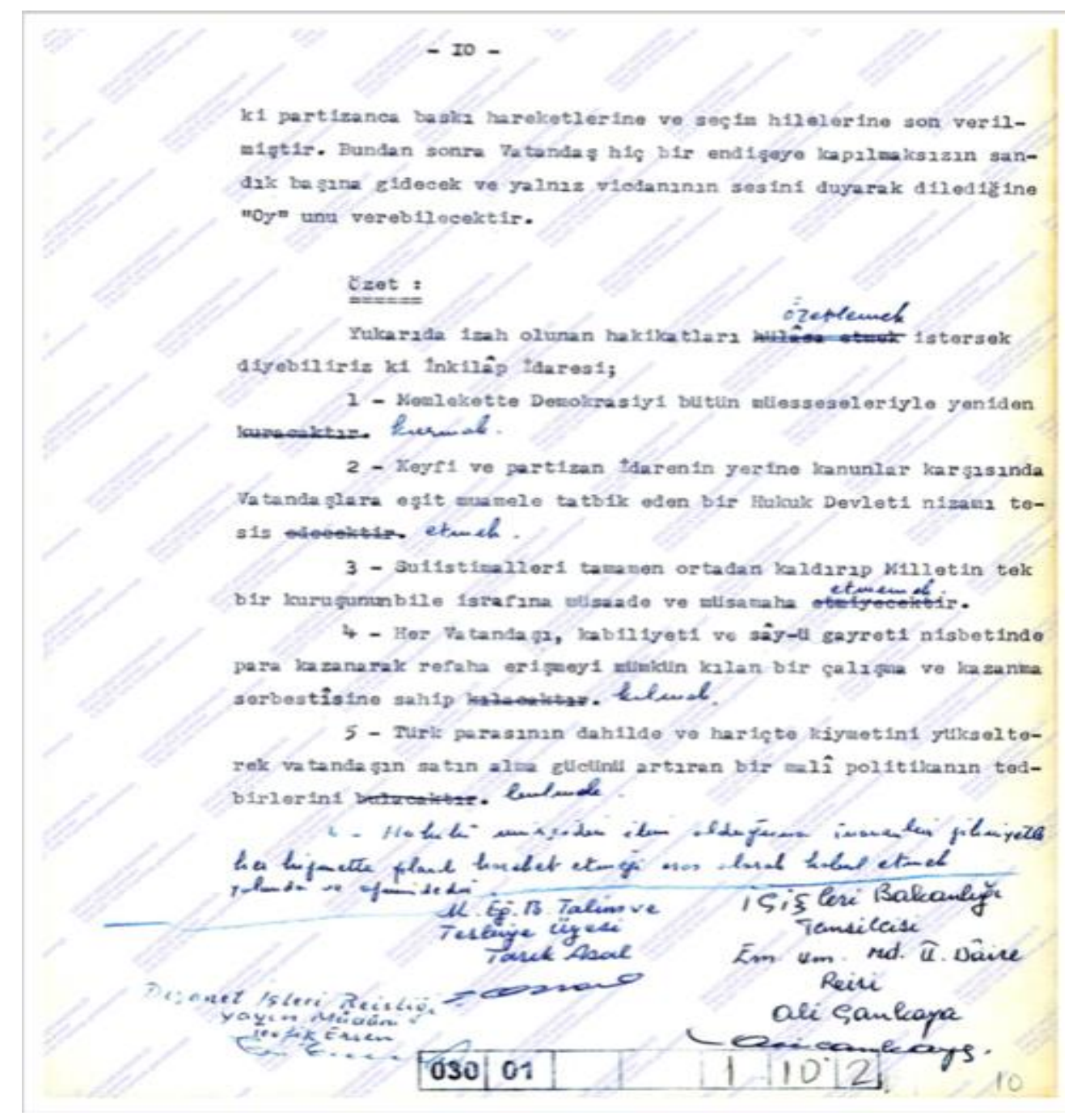

Ek 2: 27 Mayıs 1960 Askeri Darbesinin yapılma sebeplerini gösteren beyanatların özeti (Başkanlık Cumhuriyet Arşivi (BCA), 30-1-0-0/1-10-2, 08. 07. 1960). 


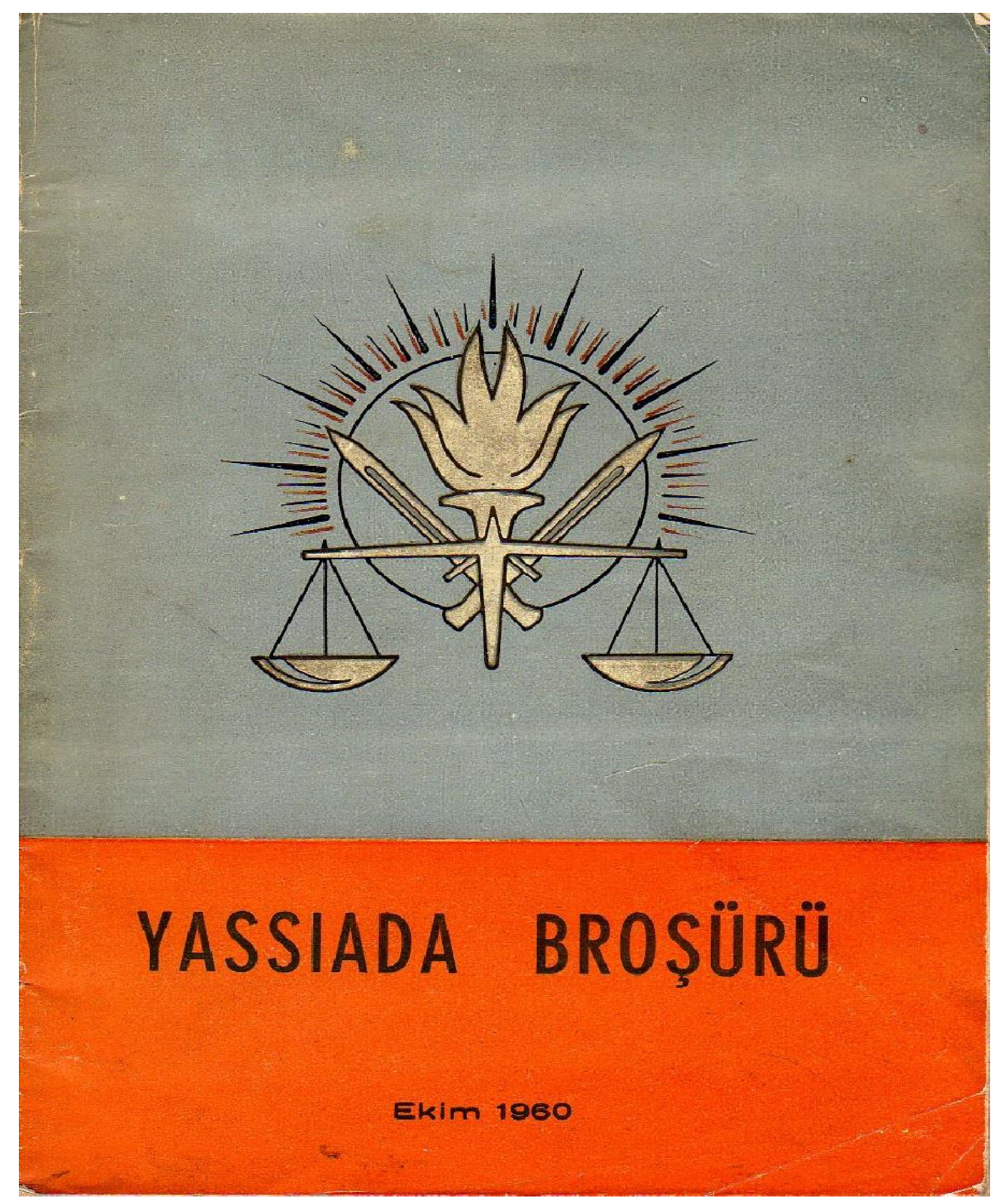

Ek 3: YASSIADA BROŞÜRÜ.(Ekim -1960). İstanbul: T.C. Milli Birlik Komitesi İrtibat Bürosu. 


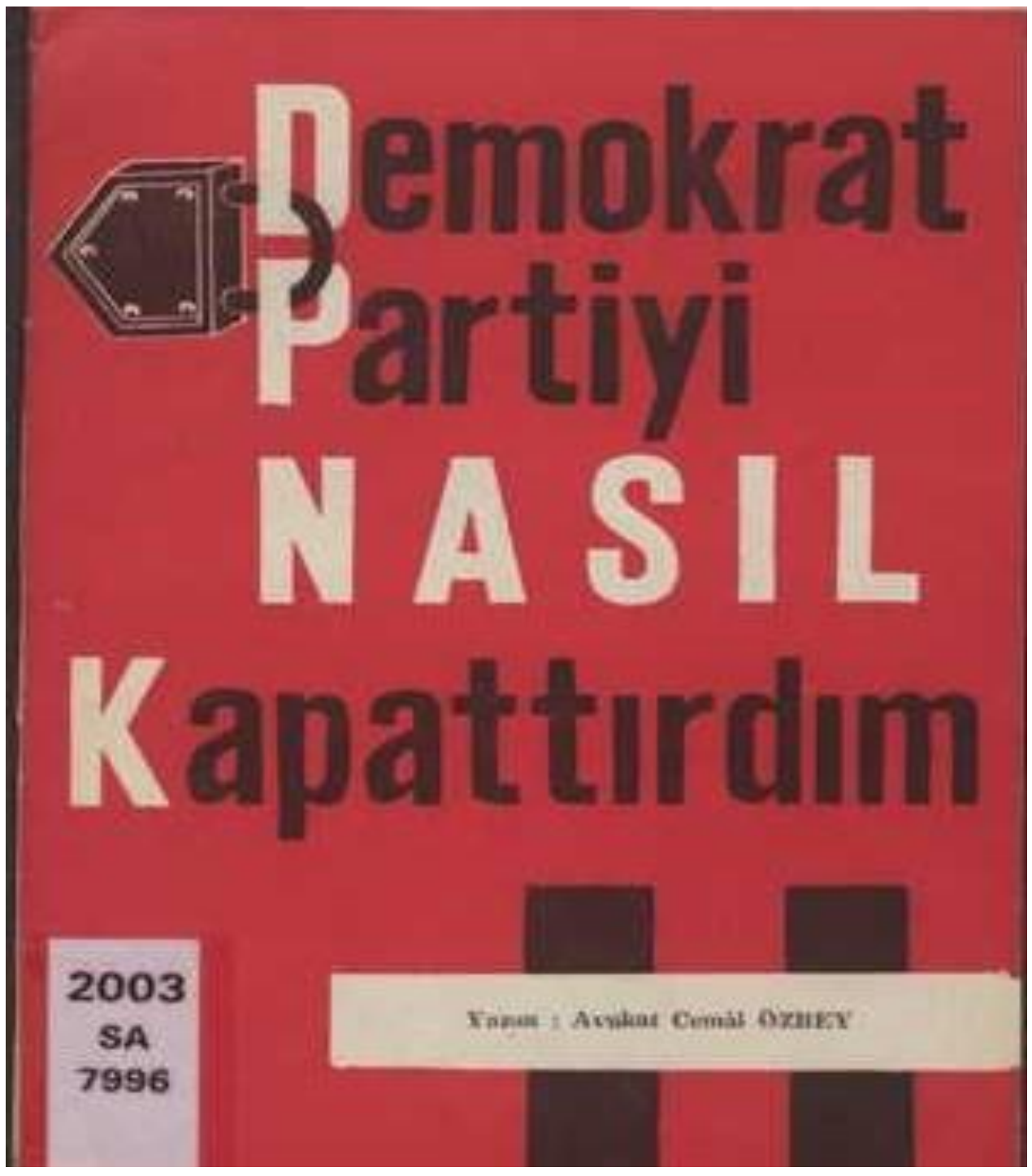

Ek 4: ÖZBEY, C. (1961). Demokrat Parti'yi Nasıl Kapattırdım. Ankara: Emek Basım. 